\title{
Fibroblasts Modulate Intestinal Secretory Responses to Inflammatory Mediators
}

Helen M. Berschneider and Don W. Powell*

Department of Anatomy, Physiological Sciences and Radiology, College of Veterinary Medicine, North Carolina State University, Raleigh, North Carolina 27606; and *Department of Medicine, School of Medicine and Center for Gastrointestinal Biology and Disease, University of North Carolina at Chapel Hill, Chapel Hill, North Carolina 27559

\begin{abstract}
Cultured colonic epithelial cells and fibroblasts were used to examine the interaction between these cell types during intestinal secretion. Secretory responses of $T 84$ colonic epithelial cells, measured as changes in the short-circuit current in modified Ussing chambers to bradykinin, serotonin, hydrogen peroxide, and histamine, were enhanced in the presence of fibroblasts, either in cocultures or when separate cultures of fibroblasts were acutely juxtaposed with the T84 cultures. This effect was abolished by pretreatment with indomethacin and the fibroblasts were found to release prostaglandin $E_{2}$ in response to these inflammatory mediators. Fibroblasts may exert a paracrine regulation on the secretory response of intestinal epithelial cells via the generation and release of cyclooxygenase products in response to inflammatory mediators. These studies suggest a novel function for the intestinal fibroblastic sheath: that of amplification of the inflammatory response through mesenchymal/epithelial interaction. (J. Clin. Invest. 1992. 89:484-489.) Key words: colonic epithelial cells • fibroblasts • inflammatory mediators $\bullet$ intestinal secretion
\end{abstract}

\section{Introduction}

Just beneath the intestinal epithelial cells, separated from them by the basal lamina, lies a continuous sheath of fibroblasts that forms part of the connective tissue infrastructure of the lamina propria $(1,2)$. This fibroblast layer is known to synthesize some components of the extracellular matrix that influence the differentiation of the epithelial cells (3-5). The subepithelial fibroblastic network consists of myofibroblasts with contractile capability and is thought to contribute to mucosal repair and reepithelialization by decreasing the villus surface area after an injury $(6,7)$. More recently, intestinal fibroblasts have been found to have a paracrine function (8), the synthesis and release of insulin-like growth factors which influence the growth and differentiation of a number of other cell types.

A portion of these data has been published in abstract form (1989. Gastroenterology. 96:A41).

Dr. Powell's current address is Department of Internal Medicine, 4.108 John Sealy Hospital, E-67, University of Texas Medical Branch, Galveston, TX 77550.

Address reprint requests to Dr. Berschneider, College of Veterinary Medicine, North Carolina State University, 4700 Hillsborough Street, Raleigh, NC 27606.

Received for publication 29 January 1991 and in revised form 8 October 1991.

J. Clin. Invest.

(c) The American Society for Clinical Investigation, Inc.

0021-9738/92/02/0484/06 \$2.00

Volume 89, February 1992, 484-489
Fibroblasts from nonintestinal sites synthesize and release prostaglandins in response to bradykinin $\left(\mathrm{BK}^{1} ; 9,10\right)$ and other inflammatory mediators $(11,12)$. Prostaglandins are known to stimulate $\mathrm{Cl}^{-}$secretion by intestinal epithelial cells $(13,14)$. The intimate spatial relationship between the fibroblasts and the intestinal epithelial cells and the ability of fibroblasts to synthesize and secrete compounds capable of stimulating epithelial $\mathrm{Cl}^{-}$secretion suggest the possibility that the subepithelial fibroblasts may contribute to the regulation of intestinal epithelial electrolyte transport through the paracrine release of mediators in response to neurohumoral or inflammatory agents.

\section{Methods}

Cultured cell lines. Cultured cell models were used to test this hypothesis because it is impossible to separate the native epithelial cells from the subepithelial fibroblasts and still maintain a functional epithelial sheet with which vectorial electrolyte transport can be measured. The cultured cells provide a model system in which pure populations of the desired cell types can be maintained in a viable state for extended periods under completely controlled conditions. T84 cells are a human colonic carcinoma cell line which has been shown to form monolayers of morphologically normal epithelial cells which respond to a variety of agonists with electrogenic $\mathrm{Cl}^{-}$secretion $(13,14)$. Two types of fibroblasts were studied: P2JF, a fibroblast line derived in our laboratory from porcine small intestinal mucosa (15); and BG9, a commercially available fibroblast line derived from human foreskin (Lineberger Cancer Research Center, University of North Carolina at Chapel Hill).

The porcine fibroblasts were isolated for primary culture from the small intestines of unsuckled, mixed-breed piglets $<12 \mathrm{~h}$ old (15). Jejunum and ileum were removed and rinsed with warm phosphatebuffered saline (PBS), clamped off, and filled to distension with citrate

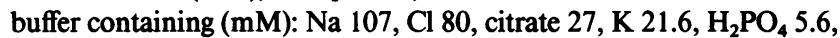
and $\mathrm{HPO}_{4} 8, \mathrm{pH} 7.2$. After a 10 -min incubation at $37^{\circ} \mathrm{C}$, the citrate buffer was drained from the segments and replaced with PBS containing $1.5 \mathrm{mM}$ EDTA and $2 \mathrm{mM}$ glucose. The segments were incubated for $10 \mathrm{~min}$ and the PBS-EDTA buffer was replaced with fresh buffer. After a final 15-25-min incubation the buffer and loosened epithelial cells and subepithelial fibroblasts were collected. The cells were pelleted and gently resuspended in growth medium: Dulbecco's modified Eagle's medium (DME)/F12 with 5\% fetal bovine serum (FBS), insulin (5 $\mathrm{mg} /$ liter), transferrin ( $5 \mathrm{mg} /$ liter), selenium ( $5 \mu \mathrm{g} /$ liter) (ITS Premix, Collaborative Research Inc., Waltham, MA) epidermal growth factor (5 $\mu \mathrm{g} /$ liter, Collaborative Research Inc.), penicillin (10,000 U/liter), and streptomycin ( $10 \mathrm{mg} / \mathrm{liter})$. The cells were plated in $100-\mathrm{mm}$ tissue culture plates (Corning Glass, Inc., Corning, NY) at a seeding density of $10^{8}$ cells per plate. Media was replaced every 3-4 d. After 2-4 wk fibroblasts were removed from the plates by using trypsin $(0.1 \%)$ with

1. Abbreviations used in this paper: ADEN, adenosine, BK, brady kinin; HIST, histamine; 5HT, serotonin; INDO, indomethacin; Isc, short-circuit current; PAF, platelet-activating factor; PD, potential difference. 
no EDTA for 10-15 min. These fibroblasts were replated and cultured separately from the epithelial cells.

Culture conditions. In preparation for the experiments, the cells were grown on polycarbonate filters which had been coated with denatured rat-tail collagen and glued to plastic rings forming wells (14). These cultures were incubated 7-10 d in DME/F12 culture medium (Gibco Laboratories, Grand Island, NY) containing 5\% fetal bovine serum (Gibco or HyClone Laboratories, Inc., Logan, UT), at $37^{\circ} \mathrm{C}$ with $5 \% \mathrm{CO}_{2} / 95 \%$ air. The filters provided mobile, permeable supports which allowed the cultured cells to be mounted in modified Ussing chambers and studied in a manner similar to traditional epithelial/mucosal preparations. The T84 cells and fibroblasts were grown separately, or together as a layered coculture. When cocultured, the fibroblasts were plated as the layer closest to the filter and electron microscopy suggests that they remained in this position (Fig. 1). Overgrowth of the cocultures by the fibroblasts was not observed during the 7-10-d culture period. The epithelial cells appeared to establish and maintain a confluent monolayer over the fibroblasts. Fibroblasts were, however, observed colonizing the basal side of the filter in cocultures maintained for $>3 \mathbf{w k}$.

Electrical experiments. The $\mathrm{Cl}^{-}$secretory responses of the T84 cells to selected inflammatory mediators were measured in modified Ussing chambers (14) by monitoring the spontaneous transepithelial electrical potential difference (PD) and the short-circuit current (Isc) obtained when the PD is clamped at zero with automatic voltage clamps (DVC1000, World Precision Instruments, Inc., New Haven, CT). The concentrations of the mediators used were derived from the literature and from preliminary dose-response studies. The mediators selected for use included: serotonin $\left(5 \mathrm{HT}, 10^{-5} \mathrm{M}\right)$, BK $\left(10^{-6} \mathrm{M}\right)$, platelet-activating factor (PAF, $\left.10^{-5} \mathrm{M}\right)$, hydrogen peroxide $\left(\mathrm{H}_{2} \mathrm{O}_{2}, 10^{-3} \mathrm{M}\right)$, histamine (HIST, $10^{-5} \mathrm{M}$ ), adenosine (ADEN, $10^{-5} \mathrm{M}$ ), leukotriene $\mathrm{C}_{4}$ and $\mathrm{D}_{4}$ $\left(\mathrm{LTC}_{4}\right.$ and $\left.\mathrm{LTD}_{4}, 10^{-6} \mathrm{M}\right)$, prostaglandin $\mathrm{E}_{2}\left(\mathrm{PGE}_{2}, 10^{-9} \mathrm{M}\right.$ and $10^{-6}$ M); all from Sigma Chemical Co., St. Louis, MO; and interleukin 1 (IL-1, $8 \mathrm{U} / \mathrm{ml}$, recombinant IL-1 $\alpha$, Boerhinger Mannheim Biochemicals, Indianapolis, IN; endotoxin contamination $<0.0001 \%$ ). All of the mediators were added to the basolateral bathing solution. The cultures were bathed on both sides with $37^{\circ} \mathrm{C}$, oxygenated Ringer solution containing $10 \mathrm{mM}$ glucose. It has been previously determined that the Isc response is equivalent to the $\mathrm{Cl}^{-}$secretion by the T84 cells (13).

The effects of fibroblasts on the electrical response of the epithelial cells to secretory agonists were determined by using techniques identical to those described above except that either cocultures of T84 cells and fibroblasts were used or monolayer cultures of P2JF fibroblasts, grown separately on collagen-coated filters, were placed into the Ussing chambers back-to-back with the T 84 cultures. The fibroblasts and the additional filter and collagen layer did not contribute significantly to the transepithelial resistance. Ion transport response by the fibroblasts does not contribute to the transepithelial $\mathrm{Cl}^{-}$secretion or Isc because

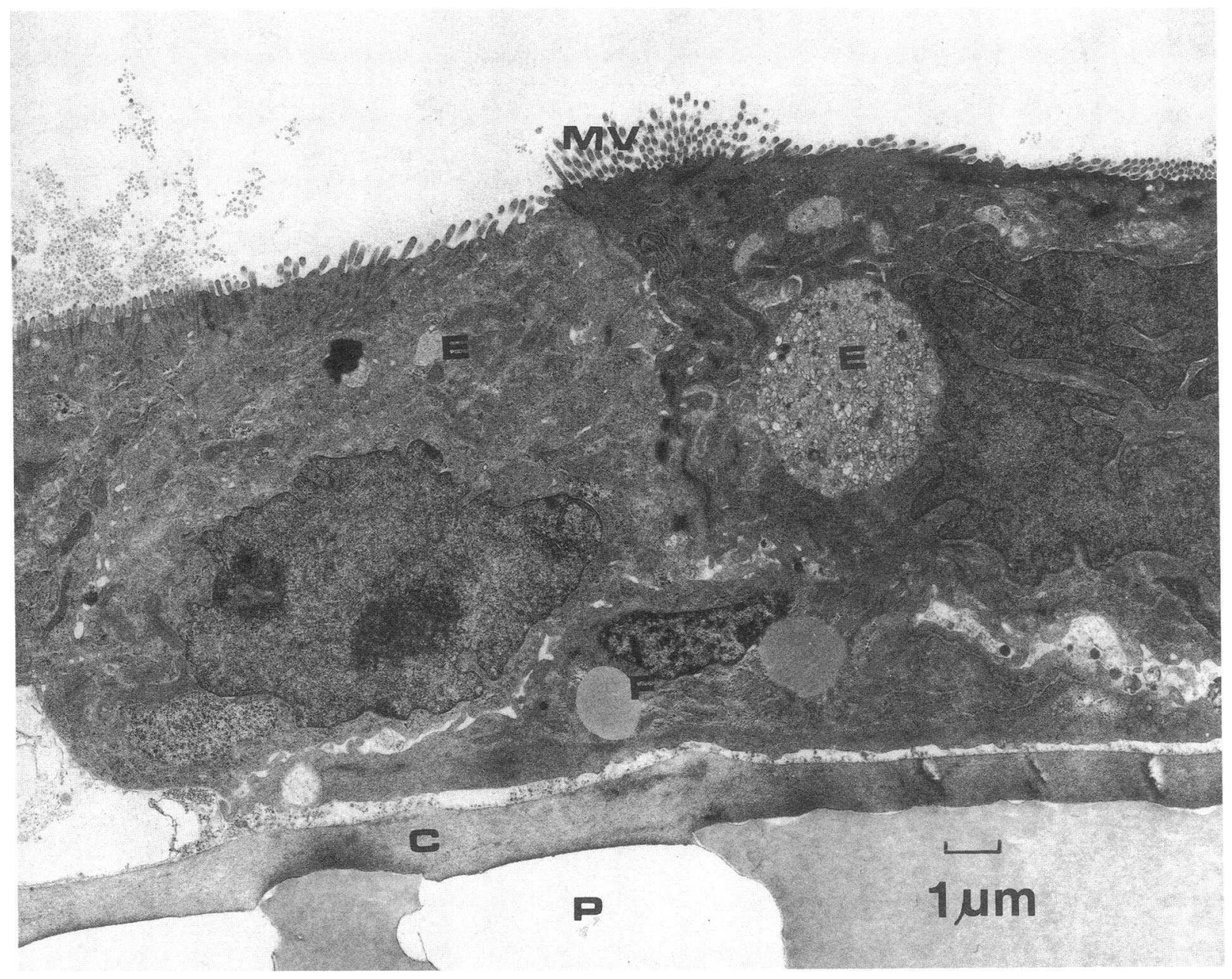

Figure 1. Electron micrograph of a T84/P2JF coculture on a collagen-coated filter. T84 epithelial cells $(E)$ with apical microvilli are seen layered over the top of another cell, presumably a fibroblast $(F)$. The cells were grown for $10 \mathrm{~d}$ on polycarbonate filters with $5-\mu \mathrm{m}$ pores $(P)$ coated with denatured rat-tail collagen $(C)$. The morphology of the lower cell $(F)$ matches that observed in cross sections of pure cultures of P2JF fibroblasts. $\times 6900$. 
the fibroblasts do not form intercellular tight junctions and, thus, cannot accomplish vectorial electrolyte transport.

A mixing experiment was performed to determine if the fibroblasts were acting in a truly paracrine fashion in the release of mediators. Fibroblasts were grown in 100-mm culture dishes for $1 \mathrm{wk}$. The culture medium was removed and the cultures were gently rinsed with warm, oxygenated Ringer solution. This solution was removed and replaced with $5.0 \mathrm{ml}$ of fresh Ringer solution. The cells were placed in the incubator and allowed to equilibrate for $1 \mathrm{~h} .5 \mu \mathrm{l}$ of $\mathrm{H}_{2} \mathrm{O}_{2}$ was added to half of the fibroblast cultures with the remainder receiving an equal volume of $\mathrm{H}_{2} \mathrm{O}$. After a 10-min incubation the solutions were collected and added to the basolateral bathing solutions of T84 cells previously mounted an equilibrated in modified Ussing chambers. The $\Delta$ Isc response of the T84 cells to the fibroblast-conditioned solutions was recorded.

Analysis of prostaglandin release. Cells grown on filters were rinsed and placed in Ringer solution containing $10 \mathrm{mM}$ glucose and incubated at $37^{\circ} \mathrm{C}$ in an atmosphere of $95 \%$ air and $5 \% \mathrm{CO}_{2}$. The cultures were equilibrated for $30 \mathrm{~min}$ before the first sample. Samples of Ringer solution were removed from each side of the filter and replaced with fresh Ringer solution every $15 \mathrm{~min}$ for $30 \mathrm{~min}$ before and after the addition of the agonist. The samples were immediately cooled and placed under nitrogen gas. They were analyzed by radioimmunoassay for PGE (antibody and reagents from Sigma Chemical Inc.; antibody did not distinguish between $\mathrm{PGE}_{2}$ and $\mathrm{PGE}_{1}$ ). Pure cultures contained $8.2 \times 10^{5} \pm 0.4 \times 10^{5} \mathrm{~T} 84$ cells per ring or $5.1 \times 10^{5} \pm 0.4 \times 10^{5}$ fibro- blasts per ring. The number of each cell type present in cocultures was not determined. Prostaglandin release was expressed as picograms of PGE released $/ 3 \mathrm{~cm}^{2}$ per $15 \mathrm{~min}$.

\section{Results}

The T84 cells form tight junctions and exhibit little basal ion transport. When stimulated with appropriate agonists, these cells actively transport $\mathrm{Cl}^{-}$from the basal to the apical solution creating an increase in the transepithelial electrical PD. When the PD is nullified by a voltage clamp, the Isc becomes a convenient signal for quantitating the net electrolyte movement from the basal to the apical solution ( $\mathrm{Cl}^{-}$secretion). Coculture of the T84 cells with fibroblasts did not have a significant effect on the transepithelial resistance of the T84 cells measured at the time of the experiments although a slightly longer period, 10 vs. $7 \mathrm{~d}$ for T84 cells alone, was required to reach maximal resistance.

Fig. 2 shows the Isc responses of the T84 cells, cultured alone, to 5HT $(A), \mathrm{BK}(B)$, and PAF $(C)$. These responses were transient, peaking within $5 \mathrm{~min}$ and were unaltered by pretrèatment of the T84 cells with indomethacin (INDO). The responses to the inflammatory mediators under the various cul-
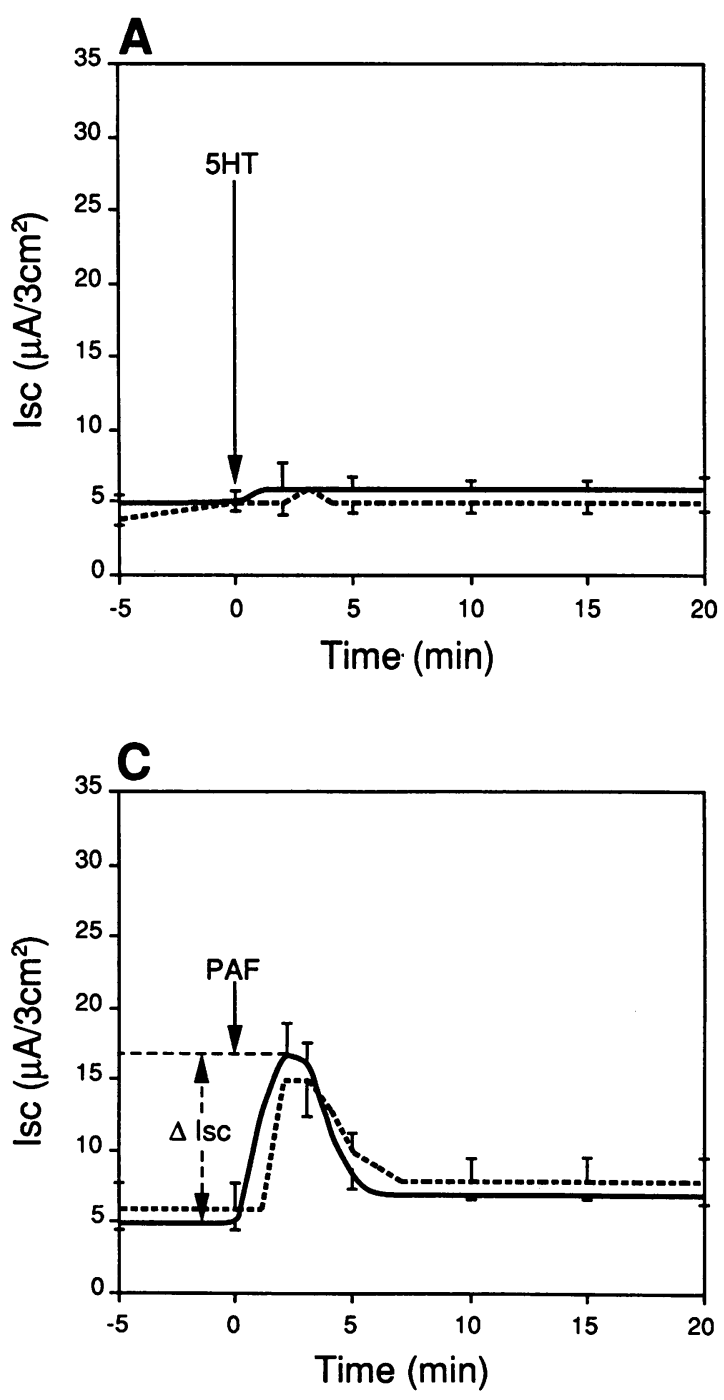

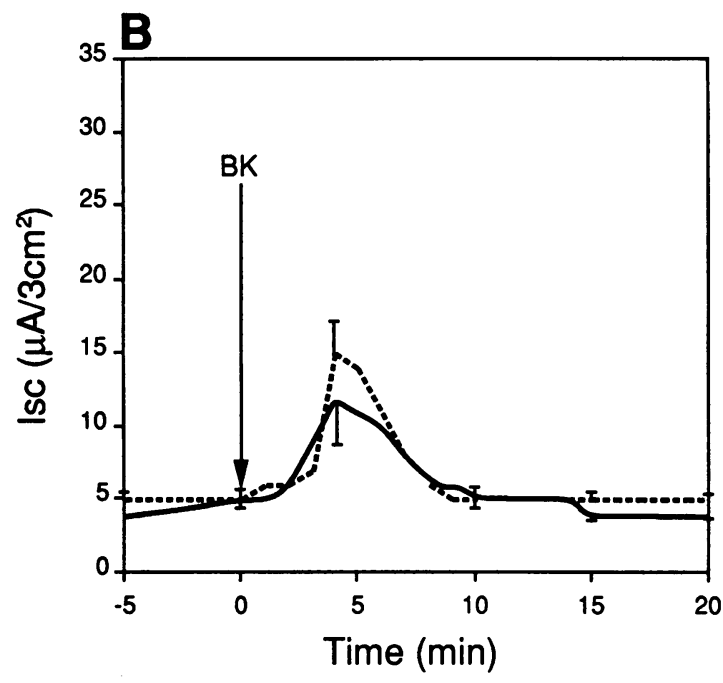

Figure 2. Time course of the T84 Isc response to selected inflammatory mediators. The Isc responses of the T84 cells mounted alone in modified Ussing chambers in the absence (solid line) or presence (dashed line) of INDO $\left(10^{-6} \mathrm{M}\right)$ are shown here as a function of time (minutes). (A) $5 \mathrm{HT} 10^{-5} \mathrm{M} ;(B) \mathrm{BK} 10^{-6} \mathrm{M} ;(C)$ PAF $10^{-5} \mathrm{M}$. The Isc is reported as the mean \pm SE. Microamperes per culture ring, area $=3 \mathrm{~cm}^{2}, n=6-15$. The $\Delta$ Isc is defined as the maximum change in Isc occurring within $15 \mathrm{~min}$ of the addition of the agonist $(C)$. 
ture conditions are reported in Table I as $\Delta \mathrm{Isc}$ (See Fig. $2 C$ for definition of $\Delta \mathrm{Isc}$ ). All of the inflammatory mediators selected for study have been shown to stimulate $\mathrm{Cl}^{-}$secretion by intact intestinal tissue (16-22). $\mathrm{H}_{2} \mathrm{O}_{2}, 5 \mathrm{HT}$, and IL-1 have little or no direct effect on the T84 cells (Table I). The responses to $\mathrm{H}_{2} \mathrm{O}_{2}$, $\mathrm{BK}$, and 5HT were significantly increased when the T84 cells were cocultured with either the P2JF or BG9 fibroblasts. The ability of the two fibroblast lines to induce the enhanced secretory responses was qualitatively similar, with one exception: the P2JF cells but not the BG9 cells responded to 5HT. While this may reflect a species- or site-specific difference in the fibroblasts $(4,5)$, it might also be the result of a spontaneous mutation during culture. Such a difference cannot be established without study of additional fibroblast lines.

These findings are compatible with two possibilities: $(a)$ that the fibroblasts are reacting to the agonists in an acute, paracrine fashion releasing mediators which, in turn, stimulate the $\mathrm{Cl}^{-}$secretion by the $\mathrm{T} 84$ cells, or $(b)$ that the fibroblasts are releasing growth factors which act slowly during chronic exposure to increase the secretory capacity of the T84 cells. These hypotheses were explored by utilizing T84 cells and fibroblasts cultured separately, then acutely juxtaposed, sandwich-style, in the Ussing chambers. As shown in Fig. 3 and Table I, the time course, but not the magnitude, of the responses to these agonists were similar in the presence of the separately cultured fibroblasts. Under these conditions, the fibroblasts enhanced the Isc response to $\mathrm{BK}, \mathrm{H}_{2} \mathrm{O}_{2}$, and $5 \mathrm{HT}$ to an 'even greater extent than in the coculture system. The response to HIST was also increased in the acutely-juxtaposed system. The responses to IL-1 and $\mathrm{LTD}_{4}$, however, were unchanged and the responses to PAF, ADEN, and $\mathrm{LTC}_{4}$ were significantly diminished. The heterogeneity of the enhanced responses indicates that this effect could not be due to a chronic alteration in T84 transport capabilities, but was more likely a response to the specific release of soluble mediators from the fibroblasts.

Many of the inflammatory mediators studied here have been shown to stimulate the synthesis and/or release of prostaglandins in tissue or cultured cell preparations $(9,16,19)$. Pretreatment of the cultures with INDO $\left(10^{-6} \mathrm{M}\right)$ inhibited the fibroblast-mediated, enhanced responses without altering the direct responses of the T84 cells to the agonists (Figs. 2 and 3, Table I), suggesting that cyclooxygenase products were involved in the enhanced responses. PGE secretion by the intestinal fibroblasts was determined since it is a potent intestinal epithelial secretagogue $(13,14,16)$ and is produced by other fibroblasts (9-12). As shown in Table II, radioimmunoassay of the bathing solutions before and after addition of the agonists indicated no basal or stimulated PGE release from the T84 cultures. Both the coculture system and the P2JF fibroblasts cultured alone released significant amounts of PGE basally and in response to BK, 5HT, $\mathrm{H}_{2} \mathrm{O}_{2}$, and HIST. A small but highly variable release of $\mathrm{PGE}$ was observed after treatment with IL-1. Subsequent experiments have demonstrated that it takes 12$24 \mathrm{~h}$ of incubation with IL-1 before significant increases in $\mathrm{PGE}_{2}$ production can be measured (23). No significant change in PGE release was detected following treatment with $\mathrm{LTC}_{4}$. PGE release stimulated by PAF and $\mathrm{LTD}_{4}$ was not determined because these two compounds interfered with the PGE assay.

Although the maximal release of PGE by the fibroblasts in response to the inflammatory mediators resulted in a concentration of $<10^{-9} \mathrm{M}$ in the chambers, the fibroblast-mediated Isc response by the T 84 cells was greater than that produced by

Table I. Isc Responses of T84 Cells and Fibroblasts to Inflammatory Mediators under Various Culture Conditions

\begin{tabular}{|c|c|c|c|c|c|}
\hline Agonist (conc) & T84 alone & $\mathrm{T} 84 / \mathrm{P} 2 \mathrm{JF}$ & $\mathrm{T} 84+\mathrm{P} 2 \mathrm{JF}$ & T84/BG9 & T84 + BG9 \\
\hline & \multicolumn{5}{|c|}{$\mu A / 3-\mathrm{cm}^{2}$ culture } \\
\hline $\mathrm{H}_{2} \mathrm{O}_{2}\left(10^{-3} \mathrm{M}\right)$ & $2.0 \pm 0.3$ & $5.9 \pm 0.7^{*}$ & $28.9 \pm 6.1^{*}$ & $17.8 \pm 2.4^{*}$ & $78.2 \pm 7.5^{*}$ \\
\hline $\mathrm{H}_{2} \mathrm{O}_{2}+\mathrm{INDO}$ & $2.8 \pm 0.8$ & $1.8 \pm 0.5$ & $6.0 \pm 1.6^{*}$ & ND & ND \\
\hline 5HT $\left(10^{-5} \mathrm{M}\right)$ & $0.8 \pm 0.2$ & $7.1 \pm 1.3^{*}$ & $26.4 \pm 7.4^{*}$ & $0.2 \pm 0.1$ & $0.1 \pm 0.1$ \\
\hline $5 \mathrm{HT}+\mathrm{INDO}$ & $0.6 \pm 0.2$ & $0.1 \pm 0.1^{*}$ & $3.0 \pm 2.5^{*}$ & ND & ND \\
\hline BK $\left(10^{-6} \mathrm{M}\right)$ & $7.2 \pm 1.4$ & $12.7 \pm 1.5^{*}$ & $14.9 \pm 4.5^{*}$ & $8.0 \pm 2.5$ & $64.1 \pm 5.1^{*}$ \\
\hline BK + INDO & $7.4 \pm 1.2$ & $3.7 \pm 0.6$ & $6.3 \pm 1.5$ & ND & ND \\
\hline HIST $\left(10^{-5} \mathrm{M}\right)$ & $17.9 \pm 2.4$ & ND & $32.9 \pm 3.9^{*}$ & ND & ND \\
\hline HIST + INDO & $14.9 \pm 3.7$ & ND & $7.4 \pm 2.1$ & ND & ND \\
\hline IL-1 (8 U/ml) & $0.6 \pm 0.4$ & ND & $3.9 \pm 2.3$ & ND & ND \\
\hline $\operatorname{LTD}_{4}\left(10^{-6} \mathrm{M}\right)$ & $35.2 \pm 10.2$ & ND & $32.8 \pm 9.7$ & ND & ND \\
\hline $\operatorname{PAF}\left(10^{-5} \mathrm{M}\right)$ & $14.0 \pm 1.1$ & $15.4 \pm 1.5$ & $3.3 \pm 1.2^{*}$ & $9.2 \pm 1.5$ & $3.5 \pm 1.4^{*}$ \\
\hline PAF + INDO & $12.4 \pm 1.6$ & $9.1 \pm 1.2^{*}$ & $1.7 \pm 0.4^{*}$ & ND & ND \\
\hline $\operatorname{ADEN}\left(10^{-5} \mathrm{M}\right)$ & $94.4 \pm 13.0$ & ND & $52.6 \pm 11.2^{*}$ & ND & ND \\
\hline $\mathrm{LTC}_{4}\left(10^{-6} \mathrm{M}\right)$ & $7.7 \pm 2.3$ & ND & $0.3 \pm 0.2^{*}$ & ND & ND \\
\hline $\mathrm{PGE}_{2}\left(10^{-9} \mathrm{M}\right)$ & $7.9 \pm 0.7$ & ND & ND & ND & ND \\
\hline $\mathrm{PGE}_{2}\left(10^{-6} \mathrm{M}\right)$ & $71.4 \pm 2.9$ & $61.4 \pm 5.4$ & $124.0 \pm 21.4^{*}$ & $73.8 \pm 13.7$ & $106.0 \pm 11.8^{*}$ \\
\hline \multicolumn{6}{|l|}{$\mathrm{PGE}_{2}\left(10^{-6} \mathrm{M}\right)$} \\
\hline + INDO & $84.0 \pm 15.7$ & $65.0 \pm 9.3$ & $134.0 \pm 21.4^{*}$ & ND & ND \\
\hline
\end{tabular}

The $\Delta$ Isc responses to inflammatory mediators were determined in modified Ussing chambers. Conditions under which responses were measured included: direct response of T84 cells alone (T84 alone), T84 cells cocultured for $10 \mathrm{~d}$ with P2JF fibroblasts (T84/P2JF) or BG9 fibroblasts $(T 84 / B G 9)$, and $T 84$ cells acutely juxtaposed to fibroblasts by mounting separate cultures back-to-back in the chambers $(T 84+P 2 J F$ and $T 84$ $+B G 9$ ). $\Delta$ Isc responses are reported as mean $\pm \mathrm{SE}, n=6-15 . \mathrm{ND}=$ not done. ${ }^{*} P<0.05$ compared to T84 alone. 

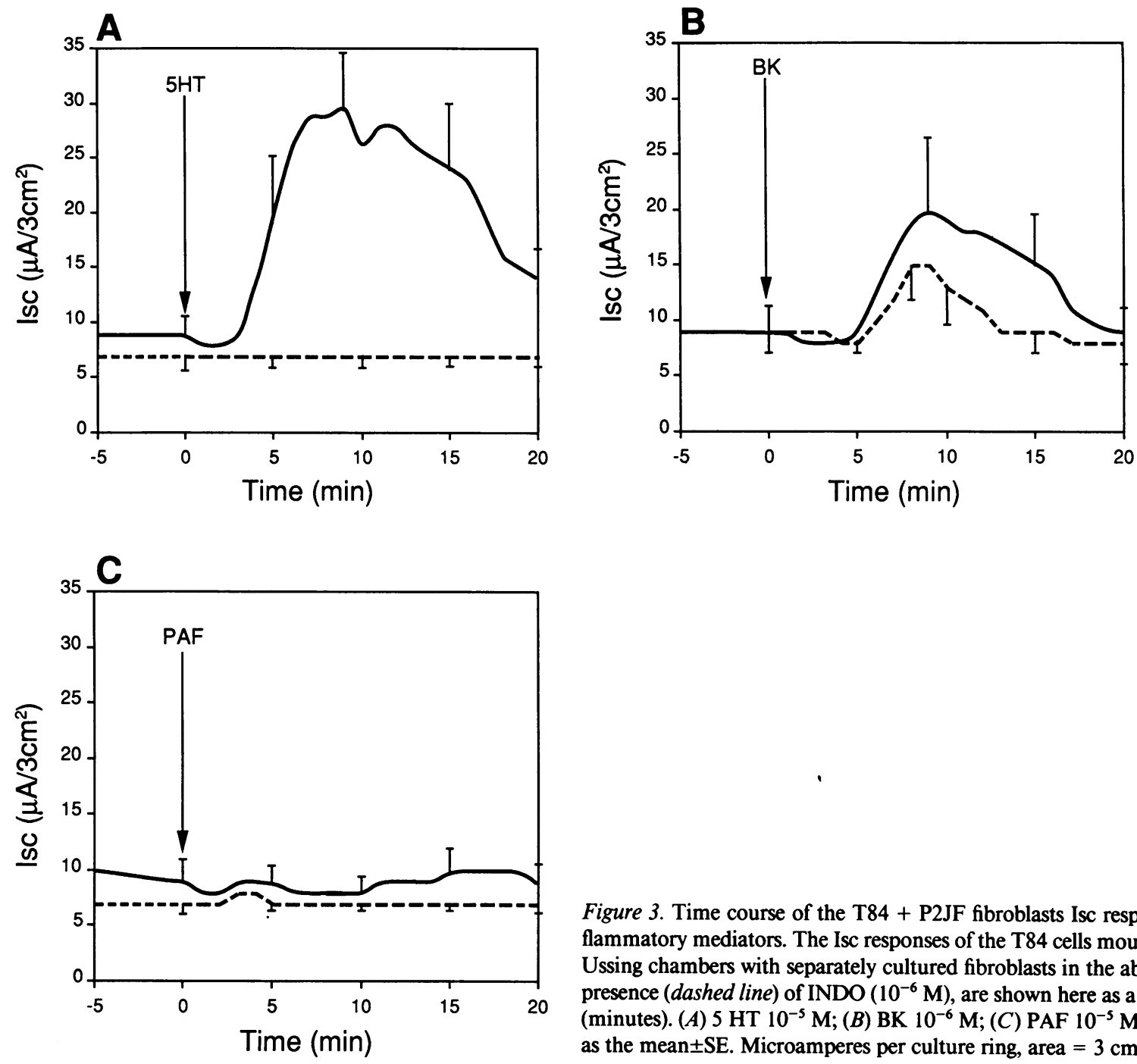

Figure 3. Time course of the T84 + P2JF fibroblasts Isc response to selected inflammatory mediators. The Isc responses of the T84 cells mounted in modified Ussing chambers with separately cultured fibroblasts in the absence (solid line) or presence (dashed line) of INDO $\left(10^{-6} \mathrm{M}\right)$, are shown here as a function of time (minutes). (A) $5 \mathrm{HT} 10^{-5} \mathrm{M}$; (B) BK $10^{-6} \mathrm{M}$; (C) PAF $10^{-5} \mathrm{M}$. The Isc is reported as the mean \pm SE. Microamperes per culture ring, area $=3 \mathrm{~cm}^{2}, n=6-15$.

$10^{-9} \mathrm{M}$ exogenous $\mathrm{PGE}_{2}$ (see Table I). It is likely, however, that the T84 cells were temporarily exposed to higher concentrations of PGE when actually secreted by stimulated, adjacent or juxtaposed fibroblasts. In the presence of juxtaposed fibro-

Table II. Prostaglandin E Release from Cultured Cells in Response to Inflammatory Mediators

\begin{tabular}{|c|c|c|c|}
\hline Agonist & T84 & T84/P2JF & P2JF \\
\hline & \multicolumn{3}{|c|}{ pg PGE release $/ 3-\mathrm{cm}^{2}$ culture $\cdot 15 \mathrm{~min}$} \\
\hline Basal & $0(18)$ & $83 \pm 15(12)$ & $261 \pm 34$ \\
\hline $5 \mathrm{HT}\left(10^{-5} \mathrm{M}\right)$ & $0(6)$ & $295 \pm 45(6)^{*}$ & $482 \pm 93(18)^{*}$ \\
\hline BK $\left(10^{-6} \mathrm{M}\right)$ & $0(6)$ & $246 \pm 72(6)^{*}$ & $612 \pm 113(18)^{*}$ \\
\hline $\mathrm{H}_{2} \mathrm{O}_{2}\left(10^{-3} \mathrm{M}\right)$ & $0(6)$ & ND & $826 \pm 94(18)^{*}$ \\
\hline HIST $\left(10^{-5} \mathrm{M}\right)$ & ND & ND & $433 \pm 33(12)^{*}$ \\
\hline IL-1 $(8 \mathrm{U} / \mathrm{ml})$ & ND & ND & $349 \pm 64$ (6) \\
\hline $\mathrm{LTC}_{4}\left(10^{-6} \mathrm{M}\right)$ & ND & ND & $176 \pm 22$ \\
\hline
\end{tabular}

Results are reported as the total PGE release occurring during the first 15 min after addition of the agonist, mean $\pm \mathrm{SE}$ (number of cultures tested)]. ${ }^{*} P<0.0125$, above basal release of PGE. blasts, but not in the cocultures, the $\Delta$ Isc response to exogenous $\mathrm{PGE}_{2}\left(10^{-6} \mathrm{M}\right.$, Table I) was greatly enhanced. Unlike the enhanced response to other mediators, the response to exogenous $\mathrm{PGE}_{2}$ was not inhibited by INDO.

The paracrine nature of the fibroblast enhancement of the secretory response was further tested with the mixing experiment. Interpretation of this experiment was made difficult by the release of significant amounts of PGE from the fibroblast cultures after rinsing. When fibroblast-conditioned Ringer solutions were added to the basolateral bathing solution of T84 cells mounted in Ussing chambers, the $\Delta \mathrm{Isc}$ response to the $\mathrm{H}_{2} \mathrm{O}_{2}$-stimulated fibroblast-conditioned solution was significantly greater than the response to the control solution $\left(\mathrm{H}_{2} \mathrm{O}\right.$ stimulated) $(18 \pm 1$ vs. $15 \pm 0.5 \mu \mathrm{A}$, respectively; $n=4, P<0.05)$. There was no response by $\mathrm{T} 84$ cells receiving an equal volume of fresh Ringer solution.

\section{Discussion}

In recent years, investigators have defined the interaction between the neuroendocrine and immune systems and the role these systems play in the regulation of intestinal electrolyte 
transport (16-22). The importance of fibroblasts in supporting the growth and differentiation of other cell types, particularly epithelial cells, has been explored in some detail $(4,5)$. While most of this work has examined the effects of chronic fibroblast-epithelial interaction, the data presented here indicate that fibroblasts may also modulate the acute inflammatory mediator-stimulated secretory responses of intestinal epithelial cells. In our model systems, the presence of fibroblasts (cocultured or acutely juxtaposed) significantly increased the $\mathrm{Cl}^{-}$secretory response of the T84 cells to BK, HIST, 5HT, and $\mathrm{H}_{2} \mathrm{O}_{2}$. The responses to some mediators, IL-1 and $\mathrm{LTD}_{4}$, were not altered, whereas with still others, PAF, $\mathrm{LTC}_{4}$, and ADEN, the response in the acutely juxtaposed system was significantly diminished. Thus, the modulation of the acute secretory response is mediator specific and does not require chronic interactions between the fibroblasts and epithelial cells and, in fact, does not even require direct contact.

The greater enhancement of the secretory response by the juxtaposed fibroblasts, as compared with cocultured fibroblasts, may be due to a greater number of fibroblasts in these cultures. The number of each type of cell in the coculture, however, was not measured. The inhibition of the fibroblastenhanced responses to the inflammatory mediators by indomethacin and the detection of PGE release from the fibroblast cultures in response to those agonists in a time frame similar to the $\mathrm{Cl}^{-}$secretory response of the T84 cells, provide strong evidence for cyclooxygenase products as mediators of this type of fibroblast-enhanced secretory response. In addition, noncyclooxygenase stimulatory products could be released from fibroblasts. This concept is supported by the INDO-insensitive enhancement of the $\Delta I s c$ response to exogenous $P_{G E}$ in the juxtaposed system. It is also possible that inhibitory, as well as stimulatory mediators are released by both the fibroblasts and the T84 cells under the different culture conditions. This might account for the diminished T84 responses (PAF, LTC 4 , ADEN) in the presence of juxtaposed fibroblasts.

The intestinal mucosa is too complex to examine the interactions of the various cell types within the intact tissue, whereas, the use of a cultured-cell model allows the study of specific cell-cell interrelationships. The structural role of fibroblasts, their contribution to basal lamina formation and potential contractile activity, and the synthesis and secretion of growth factors are recognized functions of these cells. We conclude that another function should be added to the growing list of fibroblast activities: that of the paracrine regulation of intestinal epithelial electrolyte transport.

\section{Acknowledgments}

This study was supported by grants from the National Institute of Diabetes, Digestive and Kidney Diseases, DK-34987, DK-15350; the Crohn's and Colitis Foundation of America; and the State of North Carolina.

\section{References}

1. Marsh, M. N., and J. S. Trier. 1974. Morphology and cell proliferaction of subepithelial fibroblasts in adult mouse jejunum. I. Structural features. Gastroenterology. 67:622-635.

2. Parker, F. G., E. N. Barnes, and G. I. Kaye. 1974. The pericryptal fibroblast sheath. IV. Replication, migration and differentiation of the subepithelial fibroblasts of the crypt and villus of the rabbit jejunum. Gastroenterology. 67:607-621.

3. Postlethwaite, A. E., and A. H. Kang. 1988. Fibroblasts. In Inflammation: Basic Principles and Clinical Correlates. J. I. Gallin, I. M. Goldstein and R. Snyderman, editors. Raven Press, Ltd., London. 577-597.

4. Kedinger, M., P. Simon-Assman, F. Bouziges, and K. Haffen. 1988. Epithelial-mesenchymal interactions in intestinal epithelial differentiation. Scan. J. Gastroenterol. 23(Suppl. 151):62-69.

5. Haffen, K., B. Lacroix, M. Kedinger, and P. M. Simon-Assmann. 1983. Inductive properties of fibroblasts cell cultures derived from rat intestinal mucosa on epithelial differentiation. Differentiation. 23:226-233.

6. Joyce, N. C., M. F. Haire, and G. E. Palade. 1987. Morphologic and biochemical evidence for a contractile cell network within the rat intestinal mucosa. Gastroenterology. 92:68-81.

7. Moore, R., S. Carlson, and J. L. Madara. 1989. Villus contraction aids repair of intestinal epithelium after injury. Am. J. Physiol. 257:G274-G283.

8. Han, V. K., A. J. D'Ercole, and P. K. Lund. 1987. Cellular localization of somatomedin (insulin-like growth factor) messenger RNA in the human fetus. Science (Wash. DC). 236:193-197.

9. Hong, S. L., and L. Levine. 1988. Stimulation of prostaglandin synthesis by bradykinin and thrombin and their mechanisms of action on MC5-5 fibroblasts. J. Biol. Chem. 251:5814-5816.

10. Conklin, B. R., R. M. Burch, L. R. Steranka, and J. Axelrod. 1988. Distinct bradykinin receptors mediate stimulation of prostaglandin synthesis by endothelial cells and fibroblasts. J. Pharmacol. Exp. Ther. 244:646-649.

11. Zucali, J. R., C. A. Dinarello, D. J. Oblon, M. A. Gross, L. Anderson, and R. S. Weiner. 1986. Interleukin 1 stimulates fibroblasts to produce granulocytemacrophage colony-stimulating activity and prostaglandin $\mathrm{E}_{2}$. J. Clin. Invest. 77:1837-1863.

12. Raz, A., A. Wyche, N. Siegel, and P. Needleman. 1988. Regulation of fibroblasts cyclooxygenase synthesis by interleukin-1. J. Biol. Chem. 263:30223028.

13. Weymer, A., P. Houtt, W. Liu, J. A. McRoberts, and K. Dharmsathaphorn. 1985. Chloride secretory mechanism induced by prostaglandin $E_{1}$ in a colonic epithelial cell line. J. Clin. Invest. 76:1828-1836.

14. Dharmsathaphorn, K., J. A. McRoberts, K. G. Mandel, L. D. Tisdale, and H. Masui. 1984. A human colonic tumor cell line that maintains vectorial electrolyte transport. Am. J. Physiol. 246:G204-G208.

15. Berschneider, H. M. 1989. Development of normal cultured small intestinal epithelial cell lines which transport $\mathrm{Na}$ and $\mathrm{Cl}$. Gastroenterology. 96:A41.

16. Bern, M. J., C. W. Sturbaum, S. S. Karayalcin, H. M. Berschneider, J. T. Wachsman, and D. W. Powell. 1989. Immune system control of rat and rabbit colonic electrolyte transport: Role of prostaglandins and enteric nervous system. J. Clin. Invest. 83:1810-1820.

17. Russell, D. A. 1986. Mast cells in the regulation of intestinal electrolyte transport. Am. J. Physiol. 251:G253-G262.

18. Castro, G. A. 1982. Immunological regulation of epithelial function. Am. J. Physiol. 243:G321-G329.

19. Lawson, L. D., and D. W. Powell. 1987. Bradykinin-stimulated eicosanoid synthesis and secretion by rabbit ileal components. Am. J. Physiol. 252:G783-G790.

20. Cuthbert, A. W., P. McLaughlin, and R. R. A. Coombs. 1983. Immediate hypersensitivity reaction to B-lactoglobulin in the epithelial lining the colon of guiniea pigs fed cows milk. Int. Arch. Allergy Appl. Immun. 72:34-40.

21. Perdue, M. H., and D. G. Gall. 1986. Intestinal anaphylaxis in the rat: jejunal responses to in vitro antigen exposure. Am. J. Physiol. 250 (Gastrointest. Liver Physiol. 13):G427-G431.

22. Karayalcin, S. S., C. S. Sturbaum, J. T. Wachsman, J.-H. Cha, and D. W. Powell. 1990. Hydrogen peroxide stimulates rat intestine prostaglandin production and alters electrolyte transport. J. Clin. Invest. 86:60-68.

23. Hinterleitner, T. A., H. M. Berschneider, and D. W. Powell. 1991. Fibroblast-mediated $\mathrm{Cl}$-secretion by $\mathrm{T} 84$ cells is amplified by interleukin-1 B. Gastroenterology. 100:A690. 